\title{
GAMBARAN PENGGUNAAN ANALGETIKA PADA PASIEN PASCA BEDAH DI RUANG III DAN MELATI LANTAI 4 RSUD DR. SOEKARDJO KOTA TASIKMALAYA
}

\author{
Laila Awaliyah Darajatun, Ilham Alifiar*, Tita Nofianti \\ Program Studi Farmasi STIKes Bakti Tunas Husada Tasikmalaya \\ *email: ilhamalifiar@gmail.com
}

\begin{abstract}
ABSTRAK
Bedah merupakan tindakan yang dilakukan oleh dokter untuk mengatasi masalah pasien yang mengakibatkan kerusakan jaringan tubuh sehingga menimbulkan rasa nyeri. Nyeri adalah pengalaman perasaan emosional yang tidak menyenangkan akibat terjadinya kerusakan jaringan yang aktual maupun potensial. Penanganan nyeri umumnya menggunankan analgetik seperti golongan opioid dan Non Steroid Anti-Inflammantory Drugs. Penelitian ini bertujuan untuk mengetahui gambaran penggunaan analgetik dalam menghilangkan nyeri pasca bedah meliputi penggunaan analgetik tunggal maupun analgetik kombinasi. Penelitian ini merupakan penelitian observasional dengan desain Cross sectional dan pengambilan data dilakukan secara prospektif. Subjek pada penelitian ini adalah pasien pasca bedah yang menerima analgetik di Ruang Pasca Bedah yang dirawat di sebuah RSUD dr. Soekardjo, Kota Tasikmalaya periode AprilMei tahun 2017. Jumlah pasien yang bersedia untuk mengikuti penelitian ada 111 pasien. Data-data yang diperoleh menunjukkan analgetik yang paling banyak digunakan adalah ketorolak sebanyak 49,5\%, penggunaan terbanyak kedua adalah tramadol sebanyak 21,6\%, kemudian asam mefenamat sebanyak $22,5 \%$ dan parasetamol sebanyak 4,5\%. Penggunaan analgetik kombinasi yaitu antara tramadol dengan ketorolak sebanyak 1,8\%. Kesimpulan dari penelitian ini adalah analgetik tunggal lebih banyak digunakan terhadap pasien pasca operasi di RSUD dr. Soekardjo, Kota Tasikmalaya.
\end{abstract}

Kata kunci: Pereda nyeri, anagesik, pasca bedah

\begin{abstract}
Surgery is a common action by doctors taken to overcome the problem of patients who got tissue damage which caused the pain. Pain is an emotional experience of unpleasant feelings as a result of actual or potential damage. The pain generally relieved using analgesia opioid or NSAIDs (Non-steroidal Anti-Inflammantory Drugs). This study aims to describe the use of analgesics in relieving post-surgical pain includes the use of a single analgesic or analgesic combination. This study was carried out using observational methods with cross sectional design. Subjects of this study were 111 patients who received postoperative analgesia in Room III and Melati $4^{\text {th }}$ floor dr. Soekardjo General Hospital Tasikmalaya city in period April-May 2017. The results show that the most widely used analgesic is ketorolac (49.5\%) follow by tramadol (21.6\%), mefenamic acid $(22.5 \%)$ and paracetamol $(4.5 \%)$ respectively. The combination analgesic used was tramadol-ketorolac (1.8\%). It can be concluded that the
\end{abstract}


single analgesic was more widely used in post surgical patients compared to analgesic combination.

Keywords: Pain reliever, analgesic, post surgery

\section{PENDAHULUAN}

Nyeri pasca operasi umumnya disebabkan oleh kerusakan jaringan yang tidak dapat dihindari dan mengakibatkan perubahan pada sistem saraf perifer dan sistem saraf pusat. Pada tahun 1990 The Royal College of Surgeons (RCS) melaporkan adanya rasa nyeri pada 30$70 \%$ pasien pasca bedah. Meskipun kejadian nyeri pasca bedah telah berkurang $2 \%$ pertahun selama 30 tahun terakhir, 30\% pasien masih mengeluh nyeri sedang dan $11 \%$ mengeluh nyeri parah (Holdcorf dan Jaggar, 2005).

Beberapa penelitian mengatakan sekitar 9 dari 10 orang di Amerika menderita rasa nyeri, nyeri merupakan alasan orang paling umum untuk mencari pengobatan. Sekitar 25 juta orang Amerika mengalami nyeri akut karena cedera atau tindakan pembedahan (Katz dkk., 2001).

Berdasarkan durasinya, nyeri dapat diklasifikasikan sebagai nyeri akut dan nyeri kronik. Nyeri akut memiliki karakteristik awitan mendadak; durasi singkat, kurang dari enam bulan sedangkan untuk nyeri kronik awitan bertahap; menetap, lebih lama dari enam bulan (Price dan Wilson, 2006).

Menurut International Association for Study of Pain (IASP) nyeri adalah pengalaman perasaan emosional yang tidak menyenangkan akibat terjadinya kerusakan aktual maupun potensial, atau menggambarkan kondisi terjadinya kerusakan. Nyeri dapat memberikan perubahan fisiologi, ekonomi, sosial, dan emosional yang berkepanjangan sehingga perlu dikelola secara baik.
Nyeri pasca bedah akan meningkatkan stres pasca bedah dan memiliki pengaruh negatif terhadap penyembuhan nyeri, setelah pembedahan kontrol nyeri sangat penting, nyeri yang dibebaskan dapat mengurangi kecemasan, bernafas lebih mudah dan dalam (Sjamsuhidajat dan Jong, 2010).

Penanganan nyeri pada umumnya menggunakan analgetik seperti gologan opioid, dan NSAID (Non Steroid AntiInflammantory Drugs). Penanganan nyeri akut yang ringan dapat diberikan NSAID, pada nyeri akut sedang menggunakan NSAID, dan opioid lemah. Sedangkan untuk nyeri yang berat menggunakan opioid kuat seperti morfin dan dikombinasi dengan NSAID disertai adjuvant (Macintyre, 2010).

\section{METODOLOGI PENELITIAN \\ Desain Penelitian}

Penelitian ini menggunakan desain penelitian observational study yang termasuk kedalam penelitian deskriptif. Jenis penelitian yang digunakan adalah cross sectional yaitu pengukuran yang dilakukan dalam waktu yang bersamaan dan berbatas waktu.

\section{Pengambilan Data}

Pengambilan data dilakukan dengan cara prospektif, yaitu penelitian bersifat longitudinal dengan mengikuti perjalanan penyakit ke depan berdasarkan urutan waktu perkembangan pasien selama pengobatan di Rumah Sakit.

\section{Populasi dan Sampel}


Populasi dalam penelitian ini adalah seluruh pasien pasca bedah di ruangan III dan Melati lantai 4 RSUD dr. Soekardjo Kota Tasikmalaya yang memenuhi kriteria inklusi dan sampel dalam penelitian ini adalah pasien pasca bedah yang menggunakan obat analgetika yang memenuhi kriteria inklusi.

\section{Tahapan Penelitian}

Penelitian dilakukan dengan tahapan-tahapan sebagai berikut:

1. Dilakukan penelusuran data mengenai pasien-pasien yang pernah menerima perlakukan bedah di RS DR Soekardjo, Tasikmalaya.

2. Meminta persetujuan pasien atau keluarganya untuk dimintai informasi dengan menjelaskan ketentuan-ketentuannya (informed consent).

3. Mengumpulkan dan mencatat datadata mengenai perlakuan yang diterima pasien setelah menjalani prosedur operasi khususnya informasi mengenai jenis-jenis analgesik yang diterima.

4. Melakukan analisa data secara statistic dan memberikan kesimpulan terhadap hasil analisa data.

\section{Analisis Data}

Data yang dikumpulkan dianalisis secara statistik, kemudian ditampilkan dalam bentuk tabel dan diberikan uraian pembahasan.

\section{HASIL DAN PEMBAHASAN}

Pada penelitian ini didapatkan 111 pasien yang memenuhi kriteria. Hasil akan disajikan yaitu meliputi demografi pasien, profil penggunaan obat dan evaluasi penggunaan obat.

\section{Demografi Pasien}

Tabel 1. Jenis Kelamin Pasien Pasca Bedah

\begin{tabular}{lcc}
\hline \multirow{2}{*}{ Jenis Kelamin } & \multicolumn{2}{c}{ Jumlah } \\
\cline { 2 - 3 } & $\boldsymbol{\Sigma}$ & $\boldsymbol{\%}$ \\
\hline Laki-laki & 60 & 54,05 \\
Perempuan & 51 & 45,95 \\
\hline \multicolumn{1}{c}{$\Sigma$} & 111 & 100 \\
\hline
\end{tabular}

Pada Tabel 1 dapat dilihat hasil penelitian terhadap jenis kelamin laki-laki lebih banyak dibandingkan penelitian terhadap perempuan yaitu $54,05 \%$ pada laki-laki dan $45,95 \%$ pada perempuan.

Tabel 2. Alamat Pasien Pasca Bedah

\begin{tabular}{ccc}
\hline Alamat & \multicolumn{2}{c}{ Jumlah } \\
\cline { 2 - 3 } Kota tasikmalaya & & \multicolumn{2}{c}{$\boldsymbol{\Sigma}$} & $\%$ \\
Kab. Tasikmalaya & 56 & 41,4 \\
Lainnya & 9 & 50,5 \\
\hline$\Sigma$ & 111 & 100 \\
\hline
\end{tabular}

Data tabel 2 diatas menunjukan bahwa daerah kabupaten Tasikmalaya lebih banyak pasien yang melakukan operasi, hal tersebut dapat terjadi karena faktor gaya hidup pasien yang dipengaruhi lingkungan. Hal ini dimungkinkan karena penduduk mengalami keterbatasan dalam mengakses fasilitas kesehatan, kondisi sosial ekonomi dan geografis di pedesaan lebih minim dibanding dengan perkotaan (Hapsari dkk., 2009).

Tabel 3. Karakteristik Umur Pasien

\begin{tabular}{lcc}
\hline \multirow{2}{*}{ Umur } & \multicolumn{2}{c}{ Jumlah } \\
\cline { 2 - 3 } & $\boldsymbol{\Sigma}$ & $\boldsymbol{\%}$ \\
\hline Anak (<11 tahun) & 7 & 6,3 \\
Remaja (12-22 tahun) & 20 & 18 \\
Dewasa (23-45 tahun) & 40 & 36 \\
Paruh baya (46-55 tahun) & 13 & 11,7 \\
Lansia (>56 tahun) & 31 & 27,9 \\
\hline \multicolumn{1}{c}{$\Sigma$} & 111 & 100 \\
\hline
\end{tabular}

Dapat dilihat pada tabel 3 bahwa pada penelitian ini pasien terbanyak adalah pada usia antara 12-22 tahun yang dikategorikan remaja dengan persentase 
36\%. Mulai umur 30 tahun, seseorang akan mulai mengalami penurunan fungsi fisiologis dan perubahan-perubahan struktur menyebabkan terjadinya penurunan kekuatan otot maupun mudahnya seseorang menderita penyakit (Sesa dan Efendi, 2015).

Tabel 4. Karakteristik Pasien Berdasarkan Tingkat Pendidikan

\begin{tabular}{lcc}
\hline \multirow{2}{*}{ Tingkat } & \multicolumn{2}{c}{ Jumlah } \\
\cline { 2 - 3 } \multicolumn{1}{c}{ pendidikan } & $\boldsymbol{\Sigma}$ & $\boldsymbol{\%}$ \\
\hline SD & 58 & 52,3 \\
SMP & 20 & 18 \\
SMA & 26 & 23,4 \\
PT & 4 & 3,6 \\
Tidak Sekolah & 3 & 2,7 \\
\hline \multicolumn{1}{c}{ Jumlah } & 111 & 100 \\
\hline
\end{tabular}

Berdasarkan tabel 4 tingkat pendidikan pasien yang paling banyak adalah tingkat SD sebanyak 58 pasien dengan persentase 52,3\%. Pendidikan diperlukan untuk mendapatkan informasi yang menunjang kesehatan sehingga dapat meningkatkan kualitas hidup, pendidikan berpengaruh pada cara berpikir, tindakan dan pengambilan keputusan seseorang dalam melakukan suatu perbuatan (Sriyono, 2015).

Berdasarkan Tabel 5 pekerjaan pasien pasca bedah paling banyak adalah perempuan yang bekerja sebagai IRT (ibu rumah tangga) sebanyak 30 pasien $(27 \%)$, sedangkan yang memiliki pekerjaan sebagai buruh sebanyak 29 pasien $(26,1 \%)$.

Hubungan pasien operasi dengan faktor pekerjaan dapat terjadi karena pekerjaan yang terlalu berat dapat mempengaruhi kesehatan dan berakibat menimbulkan penyakit. Penyakit akibat kerja atau berhubungan dengan pekerjaan dapat disebabkan oleh paparan dari lingkungan kerja, terdapat kesenjangan antara pengetahuan ilmiah tentang bagaimana bahaya-bahaya kesehatan berperan dan usaha-usaha untuk mencegahnya (Buchari, 2007).

Tabel 5. Karakteristik Pekerjaan Pasien

\begin{tabular}{lcc}
\hline \multirow{2}{*}{ Pekerjaan } & \multicolumn{2}{c}{ Jumlah } \\
\cline { 2 - 3 } \multicolumn{1}{c}{$\boldsymbol{\Sigma}$} & $\boldsymbol{\Sigma}$ & $\mathbf{\%}$ \\
\hline Buruh & 29 & 26,1 \\
IRT & 30 & 27 \\
Petani & 5 & 4,5 \\
Pelajar/Mahasiswa & 25 & 22,5 \\
Wiraswasta & 10 & 9 \\
Pedagang & 3 & 2,7 \\
Karyawan Swasta & 3 & 2,7 \\
Pensiunan & 1 & 0,9 \\
Tidak Bekerja & 5 & 4,5 \\
\hline \multicolumn{1}{c}{$\Sigma$} & 111 & 100 \\
\hline
\end{tabular}

Tabel 6. Diagnosis Pasien

\begin{tabular}{|c|c|c|}
\hline \multirow{2}{*}{ Diagnosis } & \multicolumn{2}{|c|}{ Jumlah } \\
\hline & $\Sigma$ & $\%$ \\
\hline Gangguan sistem Digestif & 42 & 37 , \\
\hline Neoplasma & 30 & 8 \\
\hline Gangguan kelenjar tiroid & 6 & 25 , \\
\hline Gangguan sistem & 9 & 2 \\
\hline genitourinaria & 13 & 5,4 \\
\hline Infeksi kulit dan jaringan & 2 & 8,1 \\
\hline Gangguan kelenjar Limfa & 9 & 11 , \\
\hline Cidera & & 7 \\
\hline & & 1,8 \\
\hline & & 8,1 \\
\hline$\Sigma$ & 111 & 100 \\
\hline
\end{tabular}

Berdasarkan Tabel 6, diagnosis yang paling banyak adalah gangguan sistem digestif yaitu sebanyak 42 pasien dengan persentase $37,8 \%$. Sistem digestif disebut juga sistem sistem pencernaan terdiri dari ronggan mulut, faring, eosophagus, lambung, usus halus, dan usus besar merupakan komponen saluran gastrointestinal. 
Tabel 7. Nilai VAS (Visual Analog Scale)

\begin{tabular}{ccc}
\hline \multirow{2}{*}{ Nilai VAS } & \multicolumn{2}{c}{ Jumlah } \\
\cline { 2 - 3 } & $\boldsymbol{\Sigma}$ & $\boldsymbol{\%}$ \\
\hline $1-3$ & 102 & 91,9 \\
$4-6$ & 9 & 8,1 \\
\hline$\Sigma$ & 111 & 100 \\
\hline
\end{tabular}

Berdasarkan Tabel 7 tingkat keparahan nyeri padapasien pasca bedah dengan nilai vas 1-3 (nyeri ringan) berjumlah 102 pasien $(91,9 \%)$, nilai VAS 4-6 (nyeri sedang) berjumlah 9 pasien $(8,1 \%)$.

Skala analog visual merupakan gambaran tentang seberapa parah nyeri yang dirasakan oleh individu, pengukuran nyeri dengan pendekatan objektif yang paling mungkin adalah menggunakan respon fisiologik tubuh terhadap nyeri itu sendiri (Tamsuri, 2006).

Tabel 8. Status Pembayaran Pasien

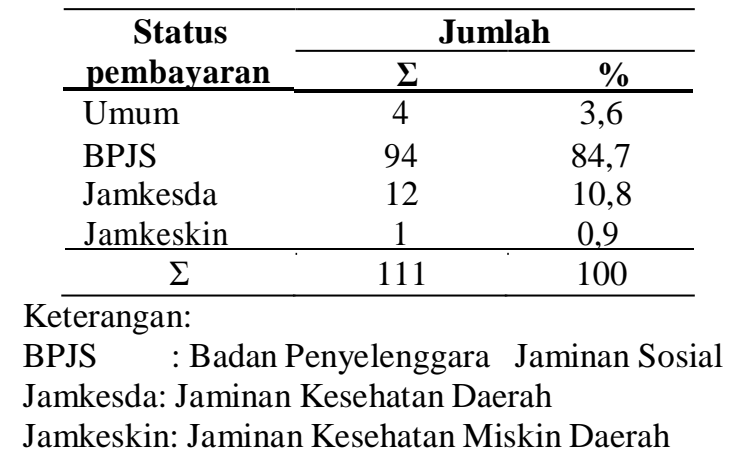

Berdasarkan Tabel 8 status pembayaran pasien yang paling banyak adalah dengan cara pembayaran BPJS dengan persentase $84,7 \%$, sedangkan untuk pembayaran dengan jamkesda $10,8 \%$, jamkeskin $0,9 \%$ dan pembayaran umum $3,6 \%$.

BPJS merupakan badan hukum publik yang dibentuk untuk menyelenggarakan program jaminan sosial. BPJS terdiri dari BPJS kesehatan dan BPJS ketenagakerjaan. Setiap peserta berhak memperoleh manfaat jaminan kesehatan yang bersifat pelayanan kesehatan perorangan, mencakup pelayanan promotif, preventif, kuratif dan rehabilitatif termasuk pelayanan obat dan bahan medis pakai sesuai dengan kebutuhan medis yang diperlukan (Anonim, 2013).

\section{Profil Penggunaan Obat}

Penggunaan obat pada pasien nyeri pasca bedah di ruang III dan Melati lt.4 adalah obat golongan analgetik narkotik yaitu tramadol, golongan analgetik nonnarkotik seperti ketorolak, asam mefenamat dan parasetamol.

Tabel 9. Penggunaan Obat Analgetik

\begin{tabular}{lccc}
\hline \multirow{2}{*}{ Nama Obat } & \multicolumn{2}{c}{ Jumlah } \\
\cline { 2 - 3 } & \multicolumn{2}{c}{$\boldsymbol{\Sigma}$} & $\boldsymbol{\%}$ \\
\hline Narkotik & & \\
Tramadol & & 21,6 \\
\hline Non narkotik & & \\
Ketorolak & 55 & 49,5 \\
Asam mefenamat & 25 & 22,5 \\
Parasetamol & 5 & 4,5 \\
\hline Kombinasi & & \\
Tramadol - ketorolak & & 1,8 \\
\hline \multicolumn{1}{c}{ Jumlah } & & 111 & 100 \\
\cline { 4 - 4 }
\end{tabular}

Berdasarkan Tabel 9 analgetik yang digunakan adalah golongan narkotik dan non-narkotik. Golongan narkotik yang digunakan yaitu tramadol, dengan persentase $21,6 \%$, penggunaan analgetik non-narkotik sebanyak 87 pasien, diantaranya penggunaan ketorolak dengan persentase $49,5 \%$, penggunaan asam mefenamat $22,5 \%$ dan parasetamol $4,5 \%$, sedangkan kombinasi tramadol dengan ketorolak $1,8 \%$.

Tramadol adalah suatu analgesik kerja sentral dengan mekanisme kerja didasarkan pada blokade penyerapan ulang serotonin. Tramadol bekerja secara sinergis yaitu agonis opioid yang lemah dan penghambat kembali neuro transmiter monoamin. Pada sistem pernafasan, tramadol lebih kecil menyebabkan depresi pernafasan dibandingkan dengan opioid lain. Onset tramadol 15-45 menit setelah 
pemberian oral sedangkan setelah pemberian rute parenteral onsetnya 5-10 menit (Raffa, 2008).

Ketorolak merupakan suatu analgetik non narkotik, obat ini merupakan OAINS yang menunjukan aktivitas antipiretik yang lemah dan antiinflamasi. Ketorolak menghambat biosintesis prostaglandin, kerjanya menghambat enzim siklooksigenase, ketorolak memberikan efek antiinflamasi dengan menghambat pelekatan granulosit pada pembuluh darah yang rusak, menstabilkan membran lisosom dan menghambat migrasi leukosit ke tempat peradangan (Hardman dan Limbird, 2012).

Ketorolak telah digunakan untuk menghilangkan gejala nyeri pasca bedah ringan sampai sedang, termasuk yang berhubungan dengan operasi perut, ginekologi, mulut, optalmik, ortopedi dan urologi. Ketorolak tidak boleh digunakan untuk analgesia selama persalinan karena inhibitor sintesis prostaglandin dapat mempengaruhi kontraksi uterus dan sirkulasi janin (American Hospital Formulary Services, 2008).

Asam mefenamat merupakan senyawa fenamat turunan $\mathrm{N}$-fenilantranilat yang termasuk golongan fenamat. Senyawa fenamat mempunyai sifat analgetik, antiinflamasi. Pada anlgesia, asam mefenamat merupakan satu-satunya fenamat yang menunjukan kerja pusat dan perifer. Asam mefenamat rute oral diabsorbsi pertama kali dari lambung dan usus selanjutnya obat akan melalui hati diserap oleh darah dan dibawa oleh darah sampai ke tempat kerjanya, konsentrasi puncak asam mefenamat dalam plasma tercapai dalam 2-4 jam (Goodman dan Gilman, 2012).

Parasetamol atau asetaminofen adalah metabolit aktif fenasetin dan berperan menghasilkan efek analgesik, merupakan inhibitor COX-1 dan COX-2 di jaringan perifer dan tidak memiliki efek antiinflamasi. Parasetamol diberikan secara oral. Dalam dosis yang besar bersifat toksik bagi hati dan ginjal (Katzung, 2015).

Kombinasi merupakan gabungan dua obat dengan khasiat yang sama dan digunakan secara bersamaan. Proses kerjanya dapat berupa antagonis dan sinergis. Antagonis terjadi ketika kerja obat pertama dikurangi atau ditiadakan sama sekali oleh obat kedua. Sinergisme terjadi ketika kekuatan obat saling memperkuat. Sinergisme ada 2 jenis yaitu adisi/sumasi (kekuatan obat saling memperkuat kombinasi kedua obat yang sama dengan jumlah masing-masing kekuatan obat tersebut) dan potensial (kekuatan kombinasi kedua obat lebih besar dari jumlah kedua obat tersebut) (Sastramihardja, 2011).

\section{KESIMPULAN}

Hasil penelitian yang dilakukan terhadap pasien pasca bedah di ruang III dan Melati lt.4 RSUD Kota Tasikmalaya periode April-Mei 2017 menunjukan bahwa analgetik yang paling banyak digunakan adalah golongan antiinflamasi nonsteroid yaitu ketorolak sebanyak 55 pasien (49,5\%), asam mefenamat 25 pasien $(22,5 \%)$, parasetamol 5 pasien $(4,5 \%)$. Sedangkan untuk penggunaan analgetik narkotik yaitu tramadol digunakan oleh 24 pasien $(21,6 \%)$, kombinasi tramadol-ketorolak pada 2 pasien $(1,8 \%)$. Pemberian analgetik ketorolac dan tramadol dilakukan secara parenteral, sedangkan asam mefenamat dan parasetamol diberikan secara oral.

\section{SARAN}

Perlu dilakukan penelitian lanjutan untuk studi kasus serupa dengan parameter-parameter uji yang lebih terperinci sehingga didapatkan data lebih detail dalam memahami kondisi pasien selama perawatan pasca bedah dan 
mendapatkan terapi obat yang efektif. Penelitian juga harus dilakukan dengan periode yang lebih lama dan penggunaan obat yang lebih beragam.

\section{DAFTAR PUSTAKA}

American Pharmacists Associstion (APHA). 2009. Drug Information Handbook: A Comprehensif Resource for All Clinicians and Healthcare Professionals $17^{\text {th }}$ Edition. Lexi Comp. U.S.A

Katz J.A., P.H. Berry, E.C. Covington J.L. Dahl dan C. Miaskowski. 2011. Pain: Current Understanding of Assessments, Managements, and Treatments. National Pharmaceutical Council. USA.

Buchari. 2007. Penyakit Akibat Kerja dan Penyakit Terkait Kerja. USU Repository. Universitas Sumatera Utara. Sumatera Utara.

Hardman, J.G. dan L.E. Limbird. 2012.Goodman \& Gilman: Dasar Farmakologi Terapi Edisi $10 \mathrm{Vol}$ II. Buku Kedokteran EGC. Jakarta.

Hapsari, D., S. Sari dan J. Pradono. 2009. Pengaruh lingkungan sehat dan perilaku hidup sehat terhadap status kesehatan. Buletin Penelitian Kesehatan. 37: 40-49.

Holdcroft, A. dan S. Jaggar. 2005. Core Topics in Pain. Cambridge University Press. United Kingdom. Katzung G Betram, Masters B Susan,
Trevor Anthony J. 2015. Farmakologi Dasar dan Klinik; Edisi 12. Vol. 1. Penerbit Buku Kedokteran EGC. Jakarta
Macintyre PE, Schug SA, Scott DA, Visser EJ, Walker. 2010. Acute Pain Management: Scientific Evidence. Australian and New Zealand College of Anaesthetists. Australia.

Price, A. Sylvia dan Wilson, M. Lorraine. 2006. Patofisiologi Konsep Klinis Proses-Proses Penyakit; Edisi-6 Vol. 2. Jakarta: Buku Kedokteran EGC.

Raffa. 2008. Basic Pharmacology Relevant To Drug Abuse Assessment: Departement Of Pharmaceutical Sciences. Journal Of Clinical Pharmacy And Therapeutics. University School of Pharmacy: Philadelphia, USA.

Sastramihardja. 2011. Farmakologi Klinik. Bandung: PT Kiblat Buku Utama.

Sesa dan Efendi. 2015. Karakteristik Penderita Hernia Inguinalis Yang Dirawat Inap Di Rumah Sakit Umum Anutapura Palu Tahun 2012. Jurnal Kesehatan Tadulako Vol.1 No.1, Januari 2015.

Sjamsuhidajat R, Jong. 2013. Buku Ajar Ilmu Bedah. Jakarta : Buku Kedokteran EGC.

Sriyono. 2015. Pengaruh Tingkat Pendidikan Dan Pemahaman Masyarakat Tentang Ikan Berformalin Terhadap Kesehatan Masyarakat. Faktor exacta, Vol. 8, No. 1.

Tamsuri, A. Seri Kebutuhan Dasar Manusia: Konsep Dan Pelaksanaan Nyeri. Jakarta: Buku Kedokteran EGC. 